\title{
Protective Effects of Cerium Oxide Nanoparticles on MC3T3-E1 Osteoblastic Cells Exposed to X-Ray Irradiation
}

\author{
Cuifen Wanga,b Eric Blough ${ }^{a, b}$ Xiaoniu Daic Omolola Olajide ${ }^{d}$ Henry Driscollde \\ John W. Leidy ${ }^{d, e}$ Mose July ${ }^{d}$ William E. Trieste Miaozong Wua, ${ }^{a, b, d}$

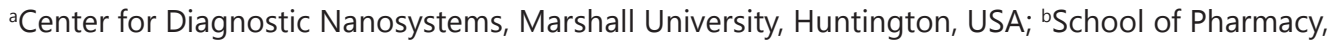 \\ Marshall University, Huntington, USA; 'Medical School of Southeast University, Nanjing, China; \\ dDepartment of Internal Medicine, Joan C. Edwards School of Medicine, Marshall University, \\ Huntington, USA; eHuntington Veterans Affairs Medical Center, Huntington, USA
}

\section{Key Words}

$\mathrm{X}$-ray irradiation $\cdot$ Cerium oxide nanoparticles $\cdot \mathrm{MC} 3 \mathrm{T3}$-E1 cells $\bullet$ Oxidative stress $\bullet$ Micronucleus - Mineralization

\begin{abstract}
Background/Aims: Exposure to ionizing radiation can result in bone damage, including decreased osteocyte number and suppressed osteoblastic activity. However, molecular mechanisms remain to be elucidated, and effective prevention strategies are still limited. This study was to investigate whether cerium oxide nanoparticles $\left(\mathrm{CeO}_{2} \mathrm{NP}\right)$ can protect MC3T3-E1 osteoblast-like cells from damaging effects of $X$-ray irradiation, and to study the underpinning mechanism(s). Methods: MC3T3-E1, a osteoblast-like cell line, was exposed to X-ray irradiation and treated with different concentration of $\mathrm{CeO}_{2}$ nanoparticles. The micronucleus frequency was counted under a fluorescence microscope. Cell viability was evaluated using MTT assay. The effects of irradiation and $\mathrm{CeO}_{2}$ nanoparticles on alkaline phosphatase activity and MC3T3-E1 mineralization were further assayed. Results: We found that the ratio of micronuclei to binuclei was dose-dependently increased with X-ray irradiation (from 2 to 6 Gy), but diminished with the increased concentration of $\mathrm{CeO}_{2} \mathrm{NP}$ treatment (from 50 to 100 $\mathrm{nM}$ ). Exposure to X-rays (6 Gy) decreased cell viability, differentiation and the mineralization, but $\mathrm{CeO}_{2} \mathrm{NP}$ treatment $(100 \mathrm{nM})$ attenuated the deteriorative effects of irradiation. Both intracellular reactive oxygen species (ROS) production and extracellular $\mathrm{H}_{2} \mathrm{O}_{2}$ concentration were increased after X-ray irradiation, but reduced following $\mathrm{CeO}_{2} \mathrm{NP}$ treatment. Similar to irradiation, exposure to $\mathrm{H}_{2} \mathrm{O}_{2}(10 \mu \mathrm{M})$ elevated the frequency of micronuclei and diminished cell viability and mineralization, while these changes were ameliorated following $\mathrm{CeO}_{2} \mathrm{NP}$ treatment. Conclusions: Taken together, our findings suggest that $\mathrm{CeO}_{2}$ nanoparticles exhibit astonishing protective effects on irradiation-induced osteoradionecrosis in MC3T3-E1 cells, and the protective effects appear to be mediated, at least partially, by reducing oxidative stress.




\section{Cellular Physiology Cell Physiol Biochem 2016;38:1510-1519 \begin{tabular}{l|l} 
and Biochemistry 10.1159/000443092 & $\begin{array}{l}\text { (c) 2016 The Author(s). Published by S. Karger AG, Basel } \\
\text { www.karger.com/cpb }\end{array}$
\end{tabular} \\ Wang et al.: Protective Effects of $\mathrm{CeO}_{2}$ Against X-Ray}

\section{Introduction}

Ionizing irradiation is an occupational health risk factor in space travel (astronauts), nuclear plants and medical imaging. For example, exposure to high-dose ionizing irradiation can cause deleterious effects on bone tissue, and osteoradionecrosis is often seen in cancer patients treated with ionizing irradiation $[1,2]$. In addition, other serious bone complications, including loss of bone mass, bone fracture and sclerosis, have been reported [3, 4]. Increased osteoblastic damage appears to play an important role in the reduced bone mineral density following irradiation [5]. It has been reported that ionizing irradiation can lead to the impeded osteoblast proliferation and differentiation, cell-cycle arrest, and even apoptosis [2, $6,7]$. However, the exact molecular mechanisms underlying irradiation-induced bone injury remain unclear, and therefore the effective radio-protectants are still limited.

Recently, the possible application of nanomaterials in biomedical fields has been drawn much attention, owing to their unique physicochemical and bioactive properties [8]. In particular, cerium oxide $\left(\mathrm{CeO}_{2}\right)$ nanoparticles are one of the most interesting nanomaterials. Its possible protection against retinal neurodegeneration, and anti-inflammatory and antioxidant activities have been recently studied [9-12]. Cerium oxide is a rare earth oxide material and exhibits the ability to cycle between the $\mathrm{Ce}^{+3}$ (fully reduced) and $\mathrm{Ce}^{+4}$ (fully oxidized) states [13]. Therefore, $\mathrm{CeO}_{2}$ nanoparticles may mimic the function of superoxide dismutase (SOD), catalase, and free radical scavenger [13-17], and can protect against the pathological progression of cardiac dysfunction and remodeling [11]. Other studies suggested that $\mathrm{CeO}_{2}$ nanoparticles can prolong the cell longevity and reduce UV lightinduced cell injury [12]. Whether $\mathrm{CeO}_{2}$ nanoparticle treatment can diminish the osteoblast injury caused by X-ray radiation is currently unclear.

On basis of the facts that $\mathrm{CeO}_{2}$ nanoparticles may possess antioxidant properties [13-17], we hypothesize that $\mathrm{CeO}_{2}$ nanoparticles can decrease osteoradionecrosis and hence protect bone cells from irradiation. In this study, we investigated the effects of X-ray irradiation and $\mathrm{CeO}_{2}$ treatment on MC3T3-E1 cells in vitro. Using hydrogen peroxide $\left.\mathrm{H}_{2} \mathrm{O}_{2}\right)$ to mimic increasing oxidative condition, we also studied the possible role of oxidative stress in X-ray induced MC3T3-E1 cell injury. Our data suggest that $\mathrm{CeO}_{2}$ nanoparticle treatment is effective in diminishing DNA damage and oxidative stress, and reducing osteoblast injury following $\mathrm{X}$-ray irradiation.

\section{Materials and Methods}

\section{Materials}

Cerium (IV) oxide dispersion nanoparticles (\#643009; particle size $(<25 \mathrm{~nm}$ ) determined by the Brunauer-Emmett-Teller method), 4',6-Diamidino-2-phenylindole dihydrochloride (DAPI), cytochalasin B, $\beta$-glycerophosphate, L-ascorbic acid, and MTT assay kit were purchased from Sigma-Aldrich (St. Louis, MO, USA). Dihydroethidium (DHE) and Amplex Red Hydrogen Peroxide Assay kit were from Molecular Probes (Eugene, OR, USA). Alkaline phosphatase (ALP) activity assay kit was from BioVision Inc. (Milpitas, CA, USA) and osteogenesis quantitation kit was from EMD Millipore (Billerica, MA, USA). Hydrogen peroxide $\left(\mathrm{H}_{2} \mathrm{O}_{2}\right.$ ) was purchased from Acros Organics (Fair Lawn, NJ, USA). MC3T3-E1 cells were purchased from the American Type Culture Collection (Manassas, VA, USA).

\section{Cell culture and treatment}

MC3T3-E1 is an osteoblastic cell line established from C57BL/6 mouse calvaria. This cell line has a similar behavior to primary osteoblasts, and provides a good model for in vitro study [18]. Cells were cultured in $\alpha$-MEM medium consisting of $10 \%$ fetal bovine serum (FBS), and maintained in an ambient of $95 \%$ air and $5 \% \mathrm{CO}_{2}$ at $37^{\circ} \mathrm{C}$, as described previously [19]. Cell medium was changed every three days. When MC3T3-E1 cells reached 80\% confluence, they were detached by treatment with $0.05 \%$ trypsin, and re-plated for experiments. Cells used in experiments were between 8 and 10 passages. The cells used in differentiation and mineralization experiments were cultured in $\alpha$-MEM medium consisting of 10\% FBS, 5 $\mathrm{mM} \beta$-glycerophosphate, and $50 \mu \mathrm{g} / \mathrm{mL}$ L-ascorbic acid after the cells reaching $80 \%$ confluence, as described 


\section{Cellular Physiology Cell Physiol Biochem 2016;38:1510-1519 \begin{tabular}{c|c} 
DOI: 10.1159/000443092 & $\begin{array}{l}\text { O 2016 The Author(s). Published by S. Karger AG, Basel } \\
\text { wwww.karger.com/cpb }\end{array}$
\end{tabular} \\ Wang et al.: Protective Effects of $\mathrm{CeO}_{2}$ Against X-Ray}

previously [20]. The cells were treated with $\mathrm{CeO}_{2}$ nanoparticles (50 or $100 \mathrm{nM}$ ) prior to the exposure to $6 \mathrm{~Gy}$ X-ray irradiation with an X-RAD 320 system (North Branford, CT, USA). In $\mathrm{H}_{2} \mathrm{O}_{2}$ experiments, the treatment was performed by adding $\mathrm{H}_{2} \mathrm{O}_{2}(10 \mu \mathrm{M})$ every day along with the medium change every three days, and the protective effects of $\mathrm{CeO}_{2}$ nanoparticles $(100 \mathrm{nM})$ were evaluated.

\section{Micronuclei (MN) scoring}

The formation of MN was evaluated by the cytokinesis block MN technique developed by Fenech and Morley [21, 22]. In brief, MC3T3-E1 cells were exposed to X-ray irradiation (2, 4 or 6 Gy) or $\mathrm{H}_{2} \mathrm{O}_{2}$ after treatment with or without $\mathrm{CeO}_{2}$ nanoparticles. At the $0,24^{\text {th }}$, and $48^{\text {th }} \mathrm{h}$ after the irradiation, or on the $6^{\text {th }}$ day after $\mathrm{H}_{2} \mathrm{O}_{2}$ exposure, the cells were incubated in the medium containing $2.5 \mathrm{mg} / \mathrm{mL}$ cytochalasin $\mathrm{B}$ for additional $48 \mathrm{~h}$, rinsed with PBS for three times, and fixed in methanol / acetic acid (9:1, v/v) for 20 min. The air-dried MC3T3-E1 cells were stained with DAPI $(10 \mu \mathrm{g} / \mathrm{mL})$, and the number of micronuclei in the binucleated cells was counted under a fluorescent microscope Carl Zeiss Axioplan-2 [23, 24]. The ratio of micronuclei to binucleated cells (1000 binucleated cells) was calculated. At least 1000 binucleated cells were scored for each sample in three separate experiments.

\section{Cell viability assay}

After X-ray irradiation or $\mathrm{H}_{2} \mathrm{O}_{2}$ exposure along with or without $\mathrm{CeO}_{2}$ nanoparticles treatment, the cell viability was measured with MTT assay kit as described previously [25, 26]. In brief, the MC3T3-E1 cells were incubated with the MTT reagent at $37^{\circ} \mathrm{C}$ for $4 \mathrm{~h}$, and then the formed formazan crystals was dissolved in $200 \mu \mathrm{L}$ of dimethyl sulphoxide (DMSO). Optical density (OD) was detected at $490 \mathrm{~nm}$ using the microplate scanning spectrophotometer (Bio-Tek, Winooski, VT, USA).

\section{ALP activity assay}

The MC3T3-E1 cells were cultured for 7 days after irradiation along with or without $\mathrm{CeO}_{2}$ treatment, rinsed with PBS for three times, and lysed in CelLytic M cell lysis reagent. Protein concentration in the supernatant was measured using a Pierce $660 \mathrm{~nm}$ protein assay reagent, and the ALP activity was determined by ALP activity assay kit. ALP activity in the supernatant was normalized to its protein concentration and expressed as units per gram protein.

\section{Mineralization assay}

The degree of mineralization (calcium-rich deposits) in MC3T3-E1 cells was determined in 6-well plates by Alizarin Red Staining (ARS) according to the manufacturer's protocols. In brief, on the $21^{\text {st }}$ day after X-ray irradiation or $\mathrm{H}_{2} \mathrm{O}_{2}$ incubation along with or without $\mathrm{CeO}_{2}$ nanoparticles treatment, MC3T3-E1 cells were fixed with $4 \%$ formaldehyde, washed thoroughly with deionized $\mathrm{H}_{2} \mathrm{O}$, and then incubated with ARS solution for $20 \mathrm{~min}$. The mineral deposits were observed and the images were captured under a light microscopy. The ARS quantitative analysis was performed by determining OD values at $405 \mathrm{~nm}$ according to the manufacturer's protocols.

\section{Dihydroethidium staining}

At the $24^{\text {th }} \mathrm{h}$ after X-ray irradiation, the intracellular reactive oxygen species (ROS) levels were assessed by dihydroethidium staining as described previously [24, 27]. In brief, at the end of treatment, the cells were incubated with $10 \mathrm{mM}$ of dihydroethidium for $1 \mathrm{~h}$ at $37^{\circ} \mathrm{C}$. After washing with PBS, the fluorescence signal was captured under a fluorescence microscope Carl Zeiss Axioplan-2. The mean fluorescence intensity per nucleus was quantified using Image J software. At least 100 nuclear per sample were evaluated at 400× magnification.

\section{Hydrogen peroxide assay}

MC3T3 cells were cultured in the 24-well plates and immediately exposed to 6 Gy X-rays after $\mathrm{CeO}_{2}$ nanoparticles treatment. At the 0 and $3^{\text {rd }} \mathrm{h}$ after irradiation, culture medium was collected and medium $\mathrm{H}_{2} \mathrm{O}_{2}$ concentrations were measured using Amplex Red Hydrogen Peroxide Assay kit according to the manufacturer's protocols. After incubation with Amplex Red reagents at room temperature for $30 \mathrm{~min}$ in the dark, fluorescence intensity was detected at $560 \mathrm{~nm}$ excitations and $590 \mathrm{~nm}$ emissions using the microplate scanning spectrophotometer (Bio-Tek, Winooski, VT, USA).

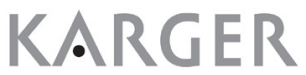




\section{Cellular Physiology Cell Physiol Biochem 2016;38:1510-1519 and Biochemistry Published online: April 07, $2016 \quad \begin{aligned} & \text { DOI: 10.1159/000443092 } 2016 \text { The Author(s). Published by S. Karger AG, Basel } \\ & \text { www.karger.com/cpb }\end{aligned}$ \\ Wang et al.: Protective Effects of $\mathrm{CeO}_{2}$ Against X-Ray}

Statistical analysis

Each experiment was repeated independently at least three times. Data were expressed as mean \pm standard error of mean. Multiple comparisons were performed using a one-way ANOVA and the Tukey post hoc test as appropriate. A P $\leq 0.05$ was considered as statistically significant.

\section{Results}

Effects of $\mathrm{CeO}_{2}$ nanoparticles on micronuclei formation in X-ray irradiated MC3T3-E1 cells

To determine the effect of X-ray irradiation on cellular chromosome breaks, the number of cells containing micronuclei in 1000 binucleated cells was counted under a fluorescence microscope. Compared to the control, irradiation dose-dependently increased the frequency of micronuclei in MC3T3-E1 cells (from 2 to 6 Gy, Fig. 1A). The micronuclei frequency at all three irradiation doses reached the peak at the $24^{\text {th }} \mathrm{h}$ after the irradiation (Fig. 1A). Importantly, the elevation of micronuclei frequency was significantly attenuated after treatment with $\mathrm{CeO}_{2}$ nanoparticles at 50 or $100 \mathrm{nM}$ (Fig. 1B).

Effects of $\mathrm{CeO}_{2}$ nanoparticles on the cell viability in X-ray irradiated MC3T3-E1 cells

The effects of irradiation and $\mathrm{CeO}_{2}$ nanoparticle treatment on MC3T3-E1 cell growth were quantified using MTT assay. As shown in Fig. 2, X-ray irradiation (6 Gy) caused a significant decrease of cell viability in MC3T3-E1 cells when compared with the control, while cell viability was improved by $100 \mathrm{nM} \mathrm{CeO}_{2}$ nanoparticles on the $4^{\text {th }}$ day after the irradiation (Fig. 2). No significant difference was observed among four groups on the first day after the irradiation (Fig. 2).

Effects of $\mathrm{CeO}_{2}$ nanoparticles on ALP activity in X-ray irradiated MC3T3-E1 cells

Alkaline phosphatase activity was determined on the $7^{\text {th }}$ day after $X$-ray irradiation and $\mathrm{CeO}_{2}$ nanoparticle treatment. Compared to the control group, ALP activity was significantly

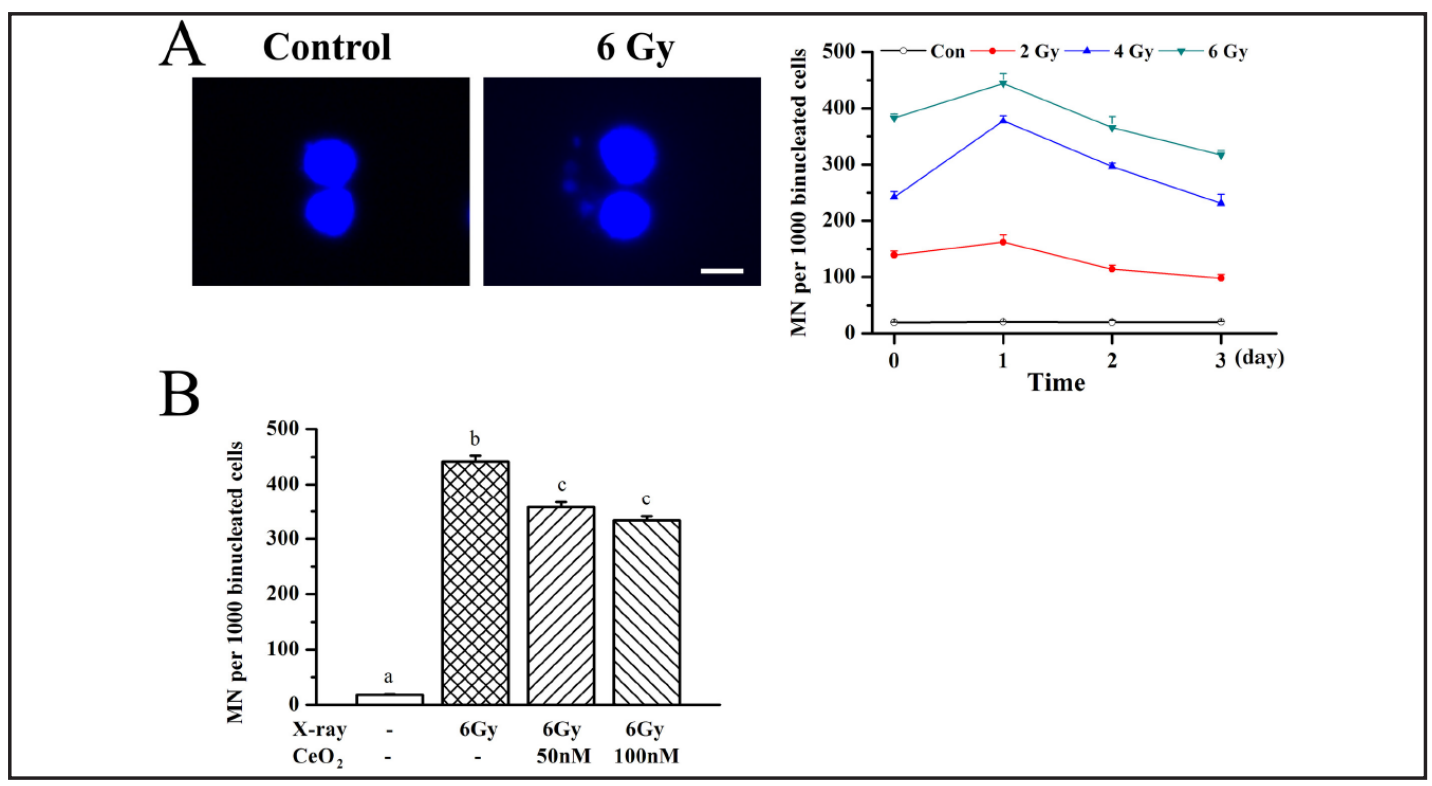

Fig. 1. Effects of X-ray irradiation and $\mathrm{CeO}_{2}$ nanoparticle treatment on the micronuclei formation. (A) The representative images of binuclei (control) and micronuclei (6 Gy) (Left panel), and the ratio of micronuclei $(\mathrm{MN}) / 1000$ binucleated cells in MC3T3-E1 cells exposed to different X-ray irradiation dose and at time points as indicated (Right panel). (B) The ratio of micronuclei/1000 binucleated cells in MC3T3-E1 cells treated with $\mathrm{CeO}_{2}$ nanoparticles ( 50 and $100 \mathrm{nM}$ ) prior to the exposure to $6 \mathrm{~Gy}$ X-ray irradiation. Values are mean \pm SEM of 3 independent experiments. abc: Groups without the same letter are significantly different (P $\leq$ 0.05). Scale bar: $10 \mu \mathrm{m}$.

\section{KARGER}




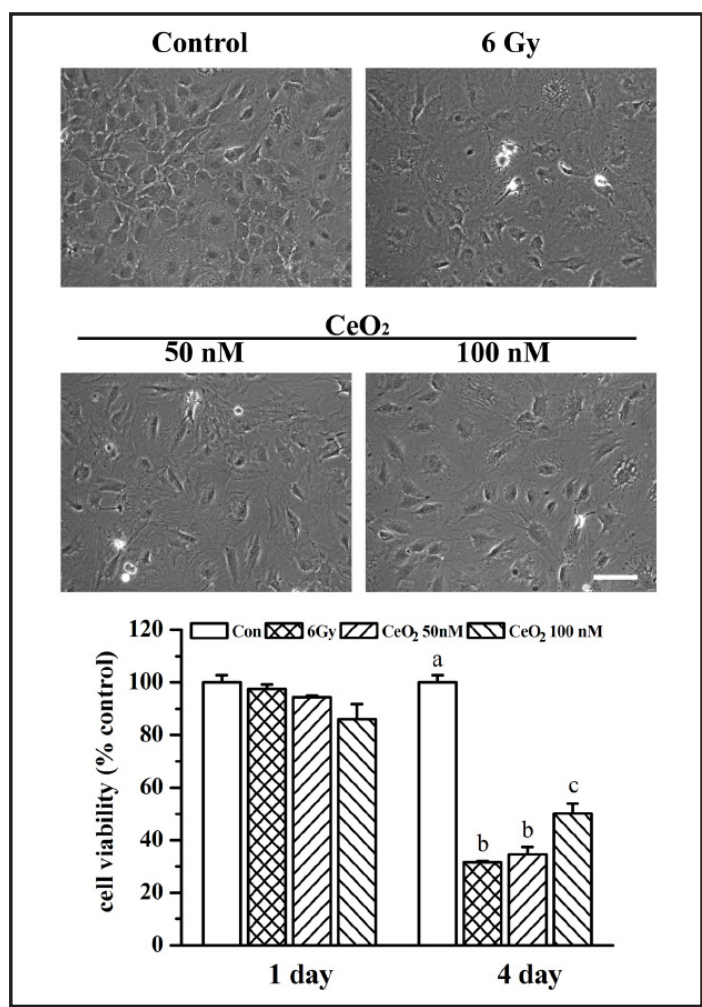

Fig. 2. Effects of $\mathrm{CeO}_{2}$ nanoparticles on the cell viability in X-ray irradiated MC3T3-E1 cells. Top panel: Representative images of cell morphology. Bottom panel: Cell viability as determined with MTT assay. Values are mean \pm SEM of 3 independent experiments. abc: Groups without the same letter are significantly different $(\mathrm{P} \leq 0.05)$. Scale bar: $50 \mu \mathrm{m}$.

decreased in the irradiation and two $\mathrm{CeO}_{2}$ treatment groups (Fig. 3). However, there was no statistically significant difference between the irradiation and $\mathrm{CeO}_{2}$ treatment groups (Fig. 3).

Effects of $\mathrm{CeO}_{2}$ nanoparticles on the mineralization in X-ray irradiated MC3T3-E1 cells

Cellular mineralization (calcium-rich deposits) was performed on the $21^{\text {st }}$ day after X-ray irradiation and $\mathrm{CeO}_{2}$ nanoparticle treatments. ARS staining showed that the number of mineralized nodules was remarkably decreased in the irradiation group when compared with the control group, but was improved in the $\mathrm{CeO}_{2}$ treatment groups (Fig. 4).

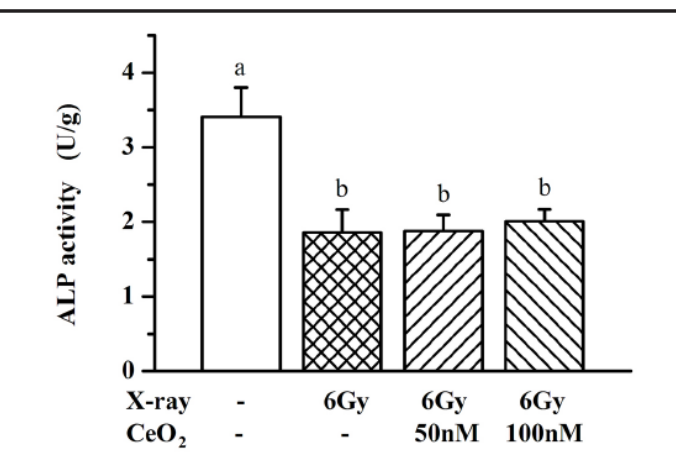

Fig. 3. Effects of $\mathrm{CeO}_{2}$ nanoparticles on the alkaline phosphatase activity in X-ray irradiated MC3T3-E1 cells. ALP activity was determined on the $7^{\text {th }}$ day after irradiation and $\mathrm{CeO}_{2}$ nanoparticle treatment. Values are mean \pm SEM of 3 independent experiments. ab: Groups without the same letter are significantly different $(P \leq 0.05)$.

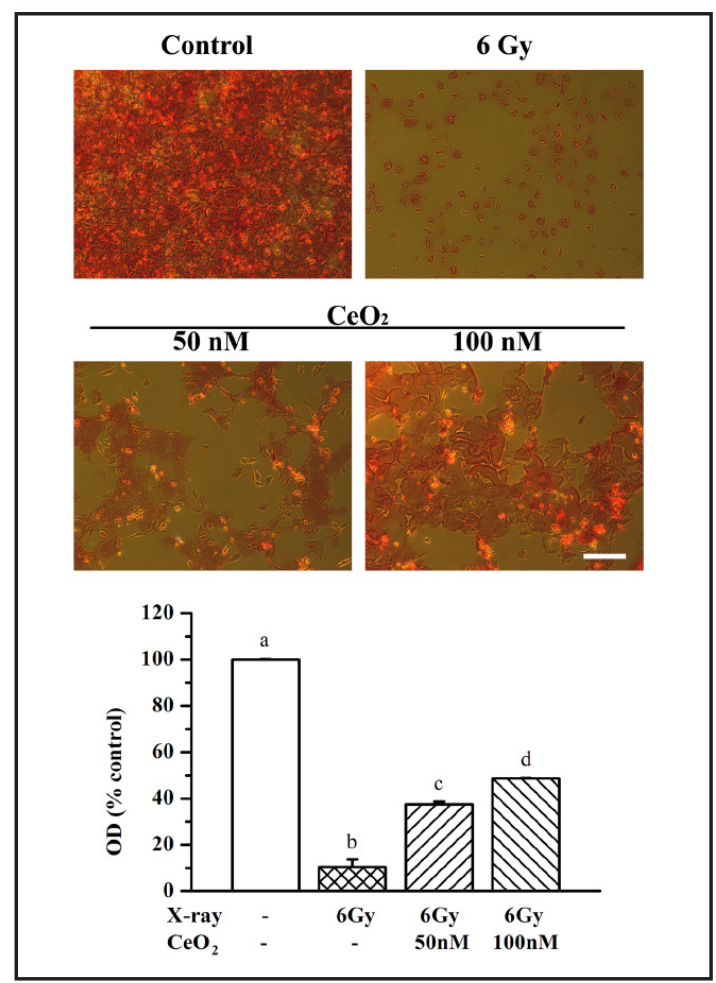

Fig. 4. Effects of $\mathrm{CeO}_{2}$ nanoparticles on the mineralization in X-ray irradiated MC3T3-E1 cells. The calcium-rich deposits in MC3T3-E1 were detected on the $21^{\text {st }}$ day after the irradiation. Top panel: Representative images of Alizarin Red staining. Bottom panel: Quantitative analysis of Alizarin Red staining. Values are mean \pm SEM of 3 independent experiments. abcd: Groups without the same letter are significantly different $(\mathrm{P} \leq 0.05)$. Scale bar: $200 \mu \mathrm{m}$. 


\section{Cellular Physiology Cell Physiol Biochem 2016;38:1510-1519

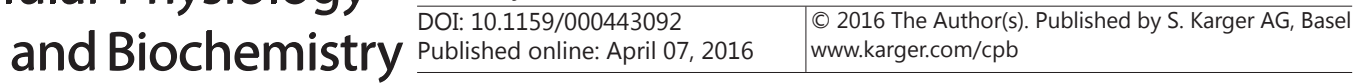 \\ Wang et al.: Protective Effects of $\mathrm{CeO}_{2}$ Against X-Ray}

Fig. 5. Effects of $\mathrm{CeO}_{2}$ nanoparticles on intracellular ROS production and extracellular $\mathrm{H}_{2} \mathrm{O}_{2}$ concentration in X-ray irradiated MC3T3-E1 cells. (A) Intracellular ROS was detected by dihydroethidium (DHE) staining at the $24^{\text {th }} \mathrm{h}$ after the treatments. Top panel: Representative images of dihydroethidium staining. Bottom panel: Quantitative analysis of dihydroethidium staining. (B) Extracellular $\mathrm{H}_{2} \mathrm{O}_{2}$ were measured by Amplex Red assay. Values are mean \pm SEM of 3 independent experiments. abc: Groups without the same letter are significantly different $(\mathrm{P} \leq$ 0.05). Scale bar: $50 \mu \mathrm{m}$.

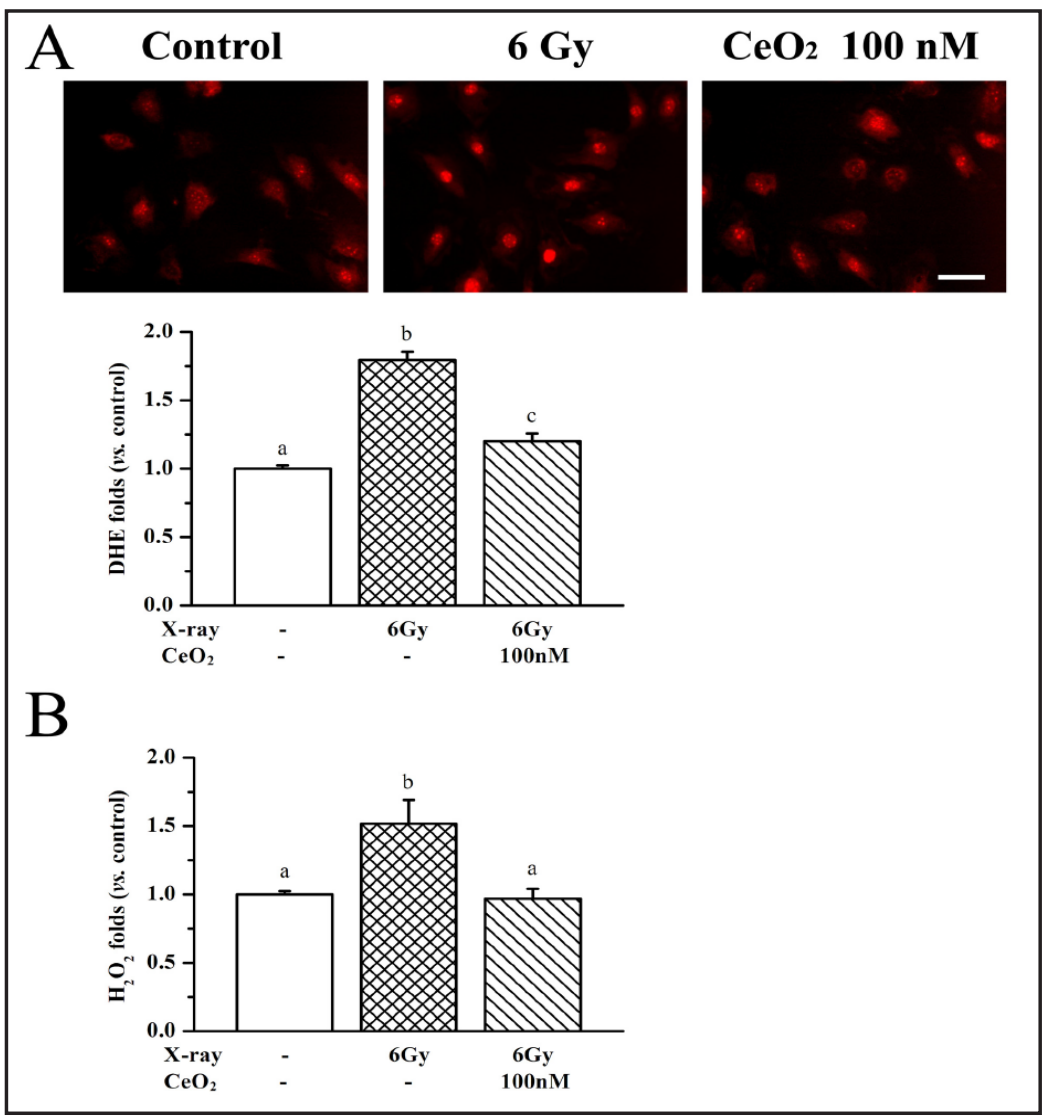

Effects of $\mathrm{CeO}_{2}$ nanoparticles on intracellular $\mathrm{ROS}$ and extracellular $\mathrm{H}_{2} \mathrm{O}_{2}$ in X-ray irradiated MC3T3-E1 cells

Dihydroethidium, a ROS indicator, intercalates within oxidized DNA and stains the nucleus a bright fluorescent red [28]. Compared to the control, the fluorescence intensity was increased in the irradiated cells, but significantly reduced following $\mathrm{CeO}_{2}$ nanoparticles treatment (Fig. 5A). Similarly, compared to the control, $\mathrm{H}_{2} \mathrm{O}_{2}$ concentration in the medium at the $3^{\text {rd }} \mathrm{h}$ (normalized to that at $0 \mathrm{~h}$ ) after irradiation was significantly increased in the irradiated cells, but $\mathrm{CeO}_{2}$ treatment restored the $\mathrm{H}_{2} \mathrm{O}_{2}$ concentration to that comparable to the control group (Fig. 5B).

Effects of $\mathrm{CeO}_{2}$ nanoparticles on $\mathrm{H}_{2} \mathrm{O}_{2}$-induced damages in MC3T3-E1 cells

To study the possible role of oxidative stress on irradiation-induced micronuclei formation and inhibition of cell viability and mineralization, $\mathrm{H}_{2} \mathrm{O}_{2}$ was used to mimic the oxidative stress condition. Similar to X-ray irradiation, the ratio of micronuclei to the binucleated cells was increased in MC3T3-E1 cells exposed to $\mathrm{H}_{2} \mathrm{O}_{2}$, but significantly attenuated after treatment with $\mathrm{CeO}_{2}$ nanoparticles $\left(100 \mathrm{nM}\right.$, Fig. 6A). Exposure to $\mathrm{H}_{2} \mathrm{O}_{2}$ caused a decrease of cell viability in MC3T3-E1 cells, while it was ameliorated after treated with $100 \mathrm{nM} \mathrm{CeO}_{2}$ nanoparticles (Fig. 6B). The number of mineralized nodules in MC3T3-E1 cells exposed to $\mathrm{H}_{2} \mathrm{O}_{2}$ was also remarkably decreased when compared to the control, but was increased following $\mathrm{CeO}_{2}$ nanoparticle treatment (Fig. 6C).

\section{Discussion}

Accumulating evidences from occupational, environmental, experimental and clinical investigations suggested that ionizing radiation can cause decreases of osteoblast proliferation, differentiation and mineralization, which if allowed to proceed unchecked 


\section{Cellular Physiology Cell Physiol Biochem 2016;38:1510-1519 \begin{tabular}{ll|l} 
DOI: 10.1159/000443092 & $\begin{array}{l}\text { O 2016 The Author(s). Published by S. Karger AG, Basel } \\
\text { www.karger.com/cpb }\end{array}$ \\
\cline { 2 - 3 } and Biochemistry
\end{tabular} \\ Wang et al.: Protective Effects of $\mathrm{CeO}_{2}$ Against X-Ray}

Fig. 6. Effects of $\mathrm{CeO}_{2}$ nanoparticles on $\mathrm{H}_{2} \mathrm{O}_{2}$-induced damages in MC3T3-E1 cells. (A) Micronuclei of MC3T3-E1 cells were counted under the fluorescence microscope on the $6^{\text {th }}$ day after treatments. (B) Cell viability of MC3T3-E1 cells was measured with MTT assay on the $3^{\text {rd }}$ day after the treatments (Scale bar: $50 \mu \mathrm{m})$. (C) The mineralization (calcium-rich deposits) of MC3T3-E1 cell was determined using the osteogenesis quantitation kit on day $21^{\text {st }}$ after the treatments (Scale bar: $200 \mu \mathrm{m}$ ). Values are mean \pm SEM of 3 independent experiments. abc: Groups without the same letter are significantly different $(\mathrm{P} \leq 0.05)$.

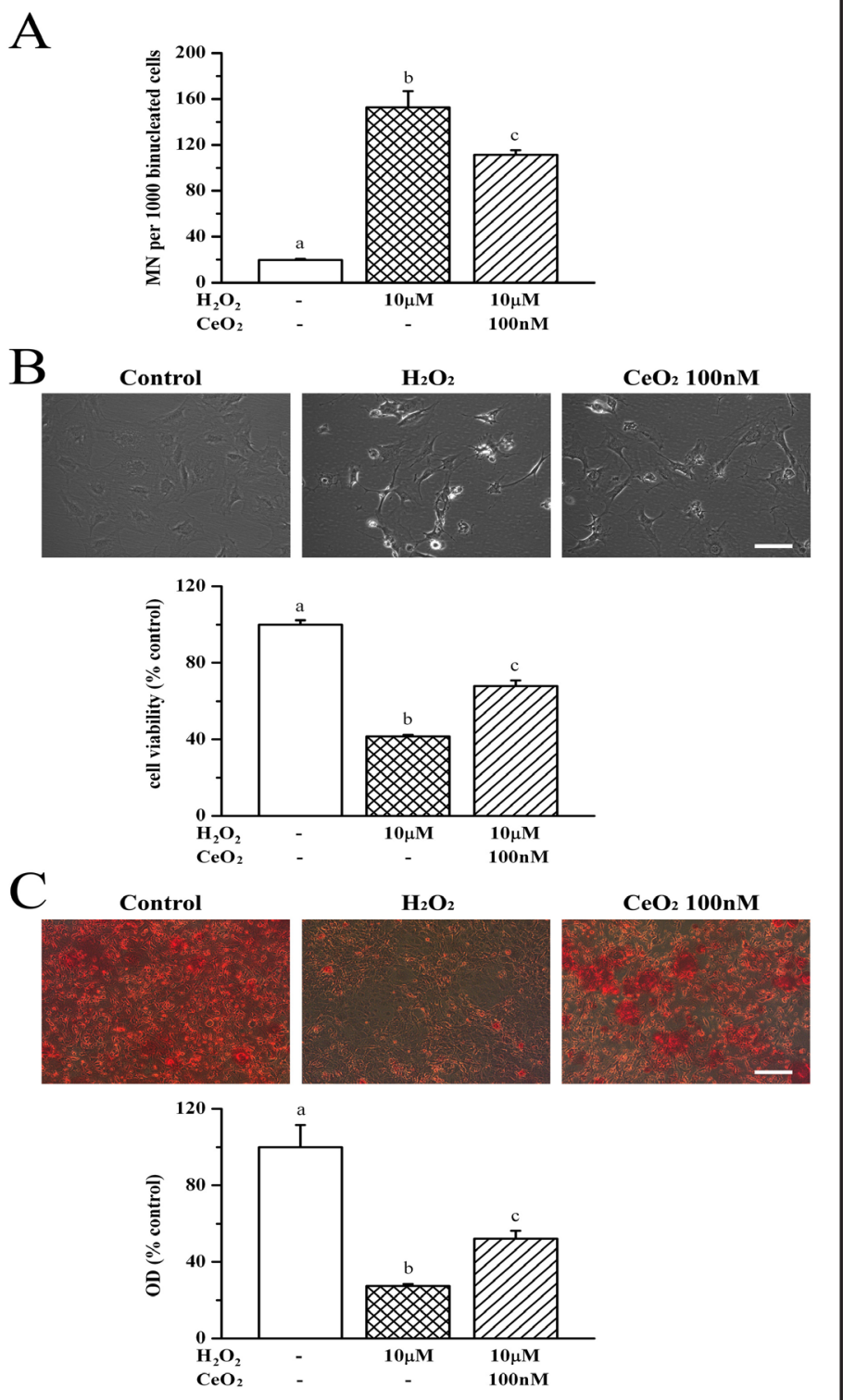

can lead to osteoradionecrosis and bone fracture [6, 29-32]. However, the effective protection strategies are still limited. In this study, we observed that $\mathrm{CeO}_{2}$ nanoparticle treatment can decrease micronuclei formation (chromosome breaks) but increase cell viability and mineralization in MC3T3-E1 cells exposed to X-ray irradiation. We also found that $\mathrm{CeO}_{2}$ nanoparticles could reduce the increase of intracellular ROS production and extracellular $\mathrm{H}_{2} \mathrm{O}_{2}$ accumulation in X-ray irradiated cells. To further investigate whether the protective effects of $\mathrm{CeO}_{2}$ nanoparticles on MC3T3-E1 cells are mediated by inhibiting oxidative stress, we demonstrated that $\mathrm{CeO}_{2}$ nanoparticle is able to attenuate the increase of micronuclei formation and the decrease of cell viability and mineralization in MC3T3-E1 cells treated with $10 \mu \mathrm{M}$ of $\mathrm{H}_{2} \mathrm{O}_{2}$. These data support that $\mathrm{CeO}_{2}$ nanoparticles exhibit protective effects in attenuating oxidative stress and cellular damages induced by X-ray irradiation in MC3T3-E1 cells.

Ionizing irradiation is a common occupational hazard to those occupations in space travel, nuclear plants, medical imaging and welding. In addition, radiation therapy in cancer patients may also lead to irradiating damages to normal tissues [1]. For example, studies have shown that high dose of ionizing irradiation can lead to osteoradionecrosis, loss of bone mass and bone fracture $[3,4,33]$. Therefore, developing effective radio-protectants is 


\section{Cellular Physiology Cell Physiol Biochem 2016;38:1510-1519

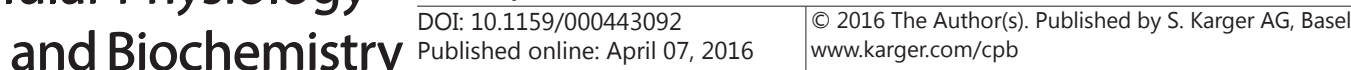 \\ Wang et al.: Protective Effects of $\mathrm{CeO}_{2}$ Against X-Ray}

more valuable. Unfortunately, the available substances that have exhibited radio-protective properties are very limited [34-36]. Since living cells consist of nearly $70 \%$ water, ionizing irradiation can lead to the formation of free radicals, as the radiation interacts with water within the cell $[22,37,38]$. Therefore, we expect that increased intracellular ROS, if present in X-ray irradiated osteoblastic cells, could damage to macromolecules, such DNAs, proteins, and lipids. To attest the notion, MC3T3-EI osteoblast-like cells were exposed to different doses of X-ray irradiation (2, 4 or 6 Gy, respectively). We found that after 24 hours exposure of MC3T3-E1 cells to 6 Gy of X-ray, intracellular ROS levels were significantly increased as detected by the dihydroethidium (Fig. 5A). Similarly, the extracellular $\mathrm{H}_{2} \mathrm{O}_{2}$ level was also elevated in the irradiated cells (Fig. 5B). To further examine whether irradiation-induced excess ROS production was associated with intracellular DNA damage and chromosome breaks, we examined the formation of micronuclei in MC3T3-E1 cells after exposure to $\mathrm{X}$-rays, and found that X-ray irradiation dose-dependently increased the ratio of micronuclei to binuclei, and the ratio reached the peak approximately at the $24^{\text {th }} \mathrm{h}$ after the irradiation (Fig. 1A). To further assure the role of oxidative stress in X-ray irradiation, hydrogen peroxide was used to mimic oxidative stress condition, and increased chromosome fragmentation was confirmed in $\mathrm{H}_{2} \mathrm{O}_{2}$-treated MC3T3-E1 cells (Fig. 6A).

To further evaluate the role of oxidative stress and the damaging effects of X-ray irradiation on bone cell growth and differentiation, we examined bone cell viability, ALP activity (as the early osteoblastic phenotypic marker [39, 40]) and mineralization (formation of mineralized nodules [41]). Consistent with the increased intracellular ROS production and extracellular $\mathrm{H}_{2} \mathrm{O}_{2}$ concentration (Fig. 5) and micronuclei frequency (Fig. 1), we found that X-ray irradiation inhibited cell viability, and decreased intracellular ALP activity and mineralization in MC3T3-E1 cells (Fig. 2-4). In parallel with increased chromosome fragmentation (Fig. 6A), our data showed that both cell viability and mineralization of MC3T3-E1 cells were diminished by $\mathrm{H}_{2} \mathrm{O}_{2}$ (Fig. 6B-C). These data together support strongly the critical role of oxidative stress in osteoradionecrosis associated with irradiation.

Cerium oxide nanoparticles have recently been shown to possess great pharmacological potentials in protection against retinal neurodegeneration, anti-inflammatory and antioxidant activities [9-12]. As a rare earth oxide material, cerium oxide exhibits amazing ability to cycle between the $\mathrm{Ce}^{+3}$ (fully reduced) and $\mathrm{Ce}^{+4}$ (fully oxidized) states [13]. Therefore, $\mathrm{CeO}_{2}$ nanoparticles may act as superoxide dismutase (SOD) and catalase mimetics $[14,15]$, and free radical scavenger $[13,16,17]$. Recent data has suggested that $\mathrm{CeO}_{2}$ nanoparticles can prolong the cell longevity and reduce UV light-induced cell injury by over $60 \%$ in cultured brain cells [12]. However, no study has been reported that whether $\mathrm{CeO}_{2}$ nanoparticle treatment can diminish the osteoblast injury after exposure to X-ray irradiation. As shown in Fig. 5, we demonstrated that $\mathrm{CeO}_{2}$ nanoparticles can diminish the production of ROS in X-ray irradiated MC3T3-E1 cells. The anti-oxidative properties of $\mathrm{CeO}_{2}$ nanoparticles were able to reduce micronuclei formation (Fig. 1 and 6A), and increase cell viability (Fig. 2 and 6B) and mineralization (Fig. 4 and 6C) in both X-ray irradiation and $\mathrm{H}_{2} \mathrm{O}_{2}$-treated cells. These findings, for the first time, demonstrate the protective effects of $\mathrm{CeO}_{2}$ nanoparticles on osteoblastic cells, and the underpinning mechanism, at least partially, by diminishing irradiation-induced oxidative stress.

In summary, our results show that $\mathrm{CeO}_{2}$ nanoparticles exhibit protective effects on MC3T3-E1 cells against irradiation or $\mathrm{H}_{2} \mathrm{O}_{2}$-induced damages, including formation of micronuclei (chromosome fragmentation), and impaired cell viability and mineralization. The radioprotective effects of $\mathrm{CeO}_{2}$ nanoparticles are mediated, at least in part, by its antioxidative activity. Future in vivo studies are necessary to attest the protective effects of $\mathrm{CeO}_{2}$ nanoparticles on bone structure and function and possibly clinical application.

\section{Acknowledgements}

This work was supported by the NASA EPSCoR\#NNX13AN08A. The authors acknowledge the support of the Joan C. Edwards School of Medicine Training Program in Endocrinology 


\section{Cellular Physiology Cell Physiol Biochem 2016;38:1510-1519 \begin{tabular}{l|l} 
DOI: 10.1159/000443092 & and Biochemistry 2016 The Author(s). Published by S. Karger AG, Basel \\
Published online: April 07, 2016 & $\begin{array}{l}\text { www.karger.com/cpb } \\
\text { Wang }\end{array}$
\end{tabular} \\ Wang et al.: Protective Effects of $\mathrm{CeO}_{2}$ Against X-Ray}

and the Huntington VA Medical Center for laboratory space and equipment. We would like to specifically thank Dr. Pier Paolo Claudio for allowing generous access to his equipment.

\section{Disclosure Statement}

All the authors declared no competing financial interests.

\section{References}

1 Mitchell MJ, Logan PM: Radiation-induced changes in bone. Radiographics 1998;18:1125-1136;quiz 12421123.

2 Szymczyk KH, Shapiro IM, Adams CS: Ionizing radiation sensitizes bone cells to apoptosis. Bone 2004;34:148-156.

3 Phulpin B, Dolivet G, Marie PY, Poussier S, Gallet P, Leroux A, Graff P, Groubach F, Bravetti P, Merlin JL, Tran N: Re-assessment of chronic radio-induced tissue damage in a rat hindlimb model. Exp Ther Med 2010;1:553-560.

4 Jia D, Gaddy D, Suva LJ, Corry PM: Rapid loss of bone mass and strength in mice after abdominal irradiation. Radiat Res 2011;176:624-635.

5 Hu KH, Li WX, Sun MY, Zhang SB, Fan CX, Wu Q, Zhu W, Xu X: Cadmium induced apoptosis in mg63 cells by increasing ros, activation of p38 mapk and inhibition of erk $1 / 2$ pathways. Cell Physiol Biochem 2015;36:642-654.

6 Sakurai T, Sawada Y, Yoshimoto M, Kawai M, Miyakoshi J: Radiation-induced reduction of osteoblast differentiation in c2c12 cells. J Radiat Res 2007;48:515-521.

7 Theocharopoulos N, Perisinakis K, Damilakis J, Papadokostakis G, Hadjipavlou A, Gourtsoyiannis N: Occupational exposure from common fluoroscopic projections used in orthopaedic surgery. J Bone Joint Surg Am 2003;85-A:1698-1703.

8 Nohynek GJ, Lademann J, Ribaud C, Roberts MS: Grey goo on the skin? Nanotechnology, cosmetic and sunscreen safety. Crit Rev Toxicol 2007;37:251-277.

9 Chen J, Patil S, Seal S, McGinnis JF: Rare earth nanoparticles prevent retinal degeneration induced by intracellular peroxides. Nat Nanotechnol 2006;1:142-150.

10 Das M, Patil S, Bhargava N, Kang JF, Riedel LM, Seal S, Hickman JJ: Auto-catalytic ceria nanoparticles offer neuroprotection to adult rat spinal cord neurons. Biomaterials 2007;28:1918-1925.

11 Niu J, Azfer A, Rogers LM, Wang X, Kolattukudy PE: Cardioprotective effects of cerium oxide nanoparticles in a transgenic murine model of cardiomyopathy. Cardiovasc Res 2007;73:549-559.

12 Tarnuzzer RW, Colon J, Patil S, Seal S: Vacancy engineered ceria nanostructures for protection from radiation-induced cellular damage. Nano Lett 2005;5:2573-2577.

13 Rzigalinski BA: Nanoparticles and cell longevity. Technol Cancer Res Treat 2005;4:651-659.

14 Heckert EG, Karakoti AS, Seal S, Self WT: The role of cerium redox state in the sod mimetic activity of nanoceria. Biomaterials 2008;29:2705-2709.

15 Pirmohamed T, Dowding JM, Singh S, Wasserman B, Heckert E, Karakoti AS, King JE, Seal S, Self WT: Nanoceria exhibit redox state-dependent catalase mimetic activity. Chem Commun (Camb) 2010;46:27362738.

16 Hirst SM, Karakoti AS, Tyler RD, Sriranganathan N, Seal S, Reilly CM: Anti-inflammatory properties of cerium oxide nanoparticles. Small 2009;5:2848-2856.

17 Hirst SM, Karakoti A, Singh S, Self W, Tyler R, Seal S, Reilly CM: Bio-distribution and in vivo antioxidant effects of cerium oxide nanoparticles in mice. Environ Toxicol 2013;28:107-118.

18 Sudo H, Kodama HA, Amagai Y, Yamamoto S, Kasai S: In vitro differentiation and calcification in a new clonal osteogenic cell line derived from newborn mouse calvaria. J Cell Biol 1983;96:191-198.

19 Yumoto H, Hirao K, Tominaga T, Bando N, Takahashi K, Matsuo T: Electromagnetic wave irradiation promotes osteoblastic cell proliferation and up-regulates growth factors via activation of the erk $1 / 2$ and p38 mapk pathways. Cell Physiol Biochem 2015;35:601-615. 


\section{Cellular Physiology Cell Physiol Biochem 2016;38:1510-1519

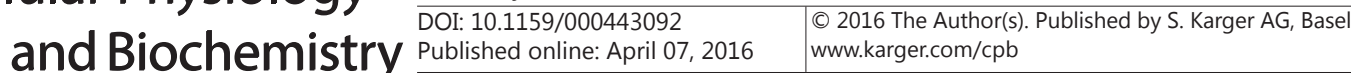 \\ Wang et al.: Protective Effects of $\mathrm{CeO}_{2}$ Against X-Ray}

20 Yamasaki K, Hagiwara H: Excess iron inhibits osteoblast metabolism. Toxicol Lett 2009;191:211-215.

21 Fenech M, Morley AA: Cytokinesis-block micronucleus method in human lymphocytes: Effect of in vivo ageing and low dose x-irradiation. Mutat Res 1986;161:193-198.

22 Theriot CA, Casey RC, Moore VC, Mitchell L, Reynolds JO, Burgoyne M, Partha R, Huff JL, Conyers JL, Jeevarajan A, Wu H: Dendro[c(60)]fullerene df-1 provides radioprotection to radiosensitive mammalian cells. Radiat Environ Biophys 2010;49:437-445.

23 Albertini RJ, Anderson D, Douglas GR, Hagmar L, Hemminki K, Merlo F, Natarajan AT, Norppa H, Shuker DE, Tice R, Waters MD, Aitio A: Ipcs guidelines for the monitoring of genotoxic effects of carcinogens in humans. International programme on chemical safety. Mutat Res 2000;463:111-172.

24 Jiang J, Huo K, Chen S, Xin Y, Xu Y, Wu Z, Yu Z, Chu PK: Intracellular chromosome breaks on silicon surface. Biomaterials 2009;30:2661-2665.

25 Wang C, Dai X, Liu H, Yi H, Zhou D, Liu C, Ma M, Jiang Z, Zhang L: Involvement of ppargamma in emodininduced hk-2 cell apoptosis. Toxicol In Vitro 2015;29:228-233.

26 Wang C, Wu X, Chen M, Duan W, Sun L, Yan M, Zhang L: Emodin induces apoptosis through caspase 3-dependent pathway in hk-2 cells. Toxicology 2007;231:120-128.

27 Wang C, Blough E, Arvapalli R, Dai X, Triest WE, Leidy JW, Masannat Y, Wu M: Acetaminophen attenuates glomerulosclerosis in obese zucker rats via reactive oxygen species/p38mapk signaling pathways. Free Radic Biol Med 2015;81:47-57.

28 Wu M, Desai DH, Kakarla SK, Katta A, Paturi S, Gutta AK, Rice KM, Walker EM, Jr., Blough ER: Acetaminophen prevents aging-associated hyperglycemia in aged rats: Effect of aging-associated hyperactivation of p38-mapk and erk1/2. Diabetes Metab Res Rev 2009;25:279-286.

29 Gal TJ, Munoz-Antonia T, Muro-Cacho CA, Klotch DW: Radiation effects on osteoblasts in vitro: A potential role in osteoradionecrosis. Arch Otolaryngol Head Neck Surg 2000;126:1124-1128.

30 Gevorgyan A, La Scala GC, Sukhu B, Leung IT, Ashrafpour H, Yeung I, Neligan PC, Pang CY, Forrest CR: An in vitro model of radiation-induced craniofacial bone growth inhibition. J Craniofac Surg 2007;18:1044-1050.

31 Gevorgyan A, Sukhu B, Alman BA, Bristow RG, Pang CY, Forrest CR: Radiation effects and radioprotection in mc3t3-e1 mouse calvarial osteoblastic cells. Plast Reconstr Surg 2008;122:1025-1035.

32 Dudziak ME, Saadeh PB, Mehrara BJ, Steinbrech DS, Greenwald JA, Gittes GK, Longaker MT: The effects of ionizing radiation on osteoblast-like cells in vitro. Plast Reconstr Surg 2000;106:1049-1061.

33 Peyre HM, Coffigny H, Reillaudou M, Beaumatin J, Morin M, Luccioni C: Transformation by radiation of rat foetal glial cells. Int J Radiat Biol 2000;76:87-94.

34 Prasad NR, Menon VP, Vasudev V, Pugalendi KV: Radioprotective effect of sesamol on gamma-radiation induced DNA damage, lipid peroxidation and antioxidants levels in cultured human lymphocytes. Toxicology 2005;209:225-235.

35 Jagetia GC, Baliga MS, Venkatesh P, Ulloor JN: Influence of ginger rhizome (zingiber officinale rosc) on survival, glutathione and lipid peroxidation in mice after whole-body exposure to gamma radiation. Radiat Res 2003;160:584-592.

36 Maurya DK, Adhikari S, Nair CK, Devasagayam TP: DNA protective properties of vanillin against gammaradiation under different conditions: Possible mechanisms. Mutat Res 2007;634:69-80.

37 Leach JK, Van Tuyle G, Lin PS, Schmidt-Ullrich R, Mikkelsen RB: Ionizing radiation-induced, mitochondriadependent generation of reactive oxygen/nitrogen. Cancer Res 2001;61:3894-3901.

38 Ogawa Y, Kobayashi T, Nishioka A, Kariya S, Hamasato S, Seguchi H, Yoshida S: Radiation-induced reactive oxygen species formation prior to oxidative DNA damage in human peripheral t cells. Int J Mol Med 2003;11:149-152.

39 Fukayama S, Tashjian AH Jr: Involvement of alkaline phosphatase in the modulation of receptor signaling in osteoblasts: Evidence for a difference between human parathyroid hormone-related protein and human parathyroid hormone. J Cell Physiol 1994;158:391-397.

40 Torii Y, Hitomi K, Yamagishi Y, Tsukagoshi N: Demonstration of alkaline phosphatase participation in the mineralization of osteoblasts by antisense rna approach. Cell Biol Int 1996;20:459-464.

41 Luppen CA, Leclerc N, Noh T, Barski A, Khokhar A, Boskey AL, Smith E, Frenkel B: Brief bone morphogenetic protein 2 treatment of glucocorticoid-inhibited mc3t3-e1 osteoblasts rescues commitmentassociated cell cycle and mineralization without alteration of runx2. J Biol Chem 2003;278:44995-45003. 